\title{
Revitalisasi Nilai-Nilai Edukatif Pendidikan Kewarganegaraan Untuk Membangun Masyarakat Berwawasan Global Berjiwa Nasionalis
}

\author{
Dodik Kariadi $^{1)}$ \\ 1) STKIP Singkawang, Singkawang, Indonesia \\ E-mail:dodik_kariadi@yahoo.com
}

\begin{abstract}
Abstrak. Saat ini bangsa Indonesia dihadapkan pada suatu masa dimana bangsa ini mengalami perkembangan dan perubahan yang sangat pesat. Pembangunan dalam bidang pendidikan yang telah dilakukan oleh pemerintah Indonesai juga telah menunjukkan hasilnya. Tetapi pendidikan warga Negara yang berpendidikan tinggi belum dapat dikatakan sebagai hasil pembangunan bangsa. Hal itu karena ada sebagian warga negara Indonesia yang memiliki pendidikan yang tinggi, namun mereka justru menghancurkan bangsa ini secara perlahan.Untuk meminimalisi perbuatan tidak bertanggung jawab dari orang berpendidikan tinggi yang bisa menggunakan ilmunya ke arah yang kurang baik maka pemerintah memunculkan PKn baik dipersekolahan maupun perguruan tinggi. Dengan memunculkan kembali nilai-nilai utama dalam PKn diharapkan dapat membangun wawasan global warga Negara yang dijiwai rasa nasionalisme. Nilainilai dasar yang perlu dikembangkan dalam membangun wawasan global dalam konteks Indonesia antara lain ketuhanan, kemanusiaan, persatuan, kerakyatan, keadilan sosial, kompetisi, menghormati orang lain, kemerdekaan dan perdamaian. Nilai-nilai dasar ini penting untuk dikembangkan dalam rangka mengembangkan wawasan global warga Negara yang semangat didalamnya tetap dijiwai oleh rasa nasionalime agar dapat berperan secara efektif dalam kancah global tanpa meninggalkan jati diri sebagai bangsa Indonesia yang memiliki Pancasila sebagai falsafah dalam kehidupan berbangsa dan bernegara.
\end{abstract}

Keywords: PKn, Wawasan Global, Nasionalis

\section{PENDAHULUAN}

Pendidikan kewarganegaran (Civic education) merupakan konsep yang mengglobal, dalam arti setiap negara memikirkan, melaksanakan dan mengevaluasi kegiatan ini. Setiap negara berkepentingan untuk mewarganegara warga negaranya. Target pertama dan utama dalam upaya menyelenggarakan pendidikan kewarganegaraan adalah warga negara yang tahu persis dan paham jati diri masyarakat,bangsa, dan negaranya.

Dalam rangka memperoleh pemahaman ini, masing-masing individu warga negara harus mempunyai pengetahuan yang luas. Pengetahuan yang diperoleh dari dalam masyarakat, bangsa dan negaranya sendiri maupun dari masyarakat, bangsa dan negara lain. Pengetahuan dari dalam diri kehidupannya untuk menemukan jati diri yang sebenarnya, sedangkan pengetahuan dari pihak lain untuk memperkuat jati dirinya. Pengetahuan dari pihak lain bukan untuk ditiru begitu saja melainkan hanya sekedar penambah cakrawala pandangan dalam rangka memperkuat jati dirinya.

Indonesia sebagai bangsa yang telah merdeka mempunyai jati diri yang sangat luar biasa, yaitu Pancasila yang berperan sebagai idiologi, pandangan hidup sekaligus dasar negara. Dibanding dengan idiologi liberal maupun komunis, ideologi Pancasila jauh lebih sempurna. Ideologi Liberal yang lebih menekankan pada kebebasan individu, ideology Komunis yang lebih mengutamakan kehidupan bersama, sementara itu ideologi Pancasila lebih menyeimbangkan kehidupan individual dengan kehidupan sosial. Ini bukan berarti ideologi pancasila merupakan paduan ideology iLiberal dengan Komunis, namun ideologi yang dibangun atas dasar kelemahan yang dimiliki oleh kedua ideologi tersebut. Kelemahan itulah yang menguatkan perlu dibentuk ideologi 
yang berbeda dari kedua ideologi; Liberal dan Komunis.

Maka melalui Pkn masyarakat Indonesia diharapkan akan memiliki yang menggelobal tetapi tetap berjiwa lokal. Wawasan global sangat diperlukan bagi semua pihak yang mempunyai kewenangan dalam mengindonesiakan WNI. Semua ini untuk meyakinkan kepada semua pihak, khususnya WNI, bahwa Indonesia mempunyai jati diri yang harus diaktualisasikan di tengah-tengah kehidupan masyarakat internasional. Indonesia mempunyai falsafah Pancasila, demokrasi Pancasila, berpegang teguh pada upaya menegakkan kedaulatan rakyat bukan kedaulatan individu. Dengan keyakinan itu, makan setiap WNI tidak mudah silau dan terpengaruh oleh falsafah, demokrasi dan kedaulatan yang dianut oleh bangsa lain kemudian menirunya.

PKn (Civic Education) merupakan mata pelajaran yang bertugas bagaimana membentuk warga negara yang baik (how a good citizen). Warga negara yang baik adalah warga negara yang sadar akan hak dan kewajibannya. Dengan kesadaran akan hak dan kewajibannya maka seorang warga negara diharapkan menjadi kritis, partisipatif dan bertanggung jawab. Ukuran warga negara yang baik tentunya sangat dipengaruhi oleh ideologi nasional masing-masing negara. Bagi bangsa Indonesia ideologi Pancasila merupakan acuan dalam membina warga negara yang baik. Pendidikan Pancasila dan Kewarganegaraan (PPKn) sebagai PKn versi Indonesia memiliki fungsi memberdayakan warga negara dalam kehidupan berbangsa dan bernegara yang sejalan dengan Pancasila.

Dalam rangka mengaktualisasikan jati diri indonesia, maka WNI perlu meneladani perilaku baik pendahulu bangsa dalam menemukan dan mengaktualisasikan jati diri indonesia. Keberanian untuk tidak mengekor pada bangsa dan negara asing, merupakan sikap dan prilaku orang yang yakin mampu bersaing dengan bangsa dan negara lain. Ini berearti apa yang diciptakan mempunyai kualitas yang dapat sejajar dengan penemuan dan ciptaaan bangsa dan negara lain. Dengan demikian jati diri menjadikan kemandirian bagi dirinya sendiri.

\section{ANALISIS}

Ilmu pengetahuan sangat penting dalam kehidupan manusia. Kita tidak bisa membayangkan bagaimana kehidupan ini tanpa ilmu pengetahuan. Tanpa ilmu pengetahuan, kita ibarat orang buta tanpa tongkat. Dengan ilmu pengetahuan yang kita miliki sekarang saja kita masih sering jatuh bangun dalam menjalani kehidupan ini. Ilmu pengetahuan dewasa ini perkembangannya sangat pesat karena terbawa oleh pengaruh globalisasi. Maka dari itu ilmu pengetahuan yang kita miliki harus selalu ditingkatkan. Bukan hanya untuk kita, tapi juga untuk generasi kita. Orang bijak bilang, ilmu pengetahuan lebih penting dari harta. Ilmu pengetahuan tidak akan bisa habis, kalau harta itu bisa habis, maka dari itu warisilah generasi kita dengan ilmu pengetahuan yang bermanfaat. Dengan ilmu pengetahuan diharapkan akan mempermudah kita dalam menjalani kehidupan.

Munculnya beragam ilmu pengetahuan yang dibawa oleh arus globalisasi telah menjadi tantangan khusus bagi setiap negara khsusunya Indonesia. Untuk membentengi masyarakat Indonesia dari pengaruh negatif globaliasi pemerintah kita mulai dari awal berdirinya bangsa ini telah menyiapkan perisai untuk menangkal halhal yang tidak diinginkan yang bisa merusak persatuan dan kesatuan bangsa Indonesia. Perisai yang dimakasud disini adalah pemerintah telah melahirkan pembelajaran $\mathrm{PKn}$ atau Citizenship education sebagai wahana yang sangat penting bagi kelangsungan serta alat untuk mempertahankan bangsa ini dari gempuran pengaruh asing yang diciptakan oleh globaliasi.

Sebelum lebih jauh membahas tentang bagaiman merevitaslisai nilai-nilai yang terkandung dalam pelajaran pedidikan kewarganegaraan yang dimana dalam hal ini akan kita gunakan sebagai wahana dalam membangun wawasan global yang dijiwai oleh rasa nasionalisme sesuai dengan judul makalah ini alangkah eloknya terlebih dahulu apabila kita memahami kosep dasar dari pendidikan 
kewarganegaraan, globalisasi\& nasionalisme itu sendiri.

\section{a. Pendidikan Kewarganegaraan}

Secara bahasa, istilah civic education oleh sebagian pakar diterjemahkan ke dalam bahasa Indonesia menjadi Pendidikan Kewargaan dan Pendidikan Kewarganegaraan. Kemudian berdasarkan literature yang saya baca Kerr[1], mengemukakan bahwa Citizenship education or civics education didefinisikan sebagai berikut: Citizenship or civics education is construed broadly to encompass the preparation of young people for their roles and responsibilities as citizens and, in particular, the role of education (trough schooling, teaching, and learning) in that preparatory process. Maksud dari pendapat Kerr ini bahwa PKn secara luas mencakup proses penyiapan generasi muda untuk mengambil peran dan tanggung jawabnya sebagai warga negara. Sedangkan secara khusus, peran pendidikan termasuk di dalamnya persekolahan, pengajaran dan belajar, dalam proses penyiapan warga negara tersebut.

Cogan [2] mengartikan civic education sebagai "the foundational course work in school designed to prepare young citizens for an active role in their communities in their adult lives", maksudnya adalah suatu mata pelajaran dasar di sekolah yang dirancang untuk mempersiapkan warga negara muda agar kelak setelah dewasa dapat berperan aktif dalam masyarakatnya.

PKn atau civic education adalah program pendidikan/pembelajaran yang secara programatik-prosedural berupaya memanusiakan (humanizing) dan membudayakan (civilizing) serta memberdayakan (empowering) manusia dalam hal ini peserta didik, diri dan kehidupannya menjadi warga negara yang baik sebagaimana tuntutan keharusan/yuridis konstitusional bangsa/negara yang bersangkutan[3].PKn adalahsarana yang tepatuntuk menginternalisasikan nilai-nilai sosial budaya masyarakat. Menurut Komalasari[4], Pendidikan Kewarganegaraan beresensikan pendidikan nilai, sehingga Pendidikan Kewarganegaraan harus memberikan perhatiannya kepada pengembangan nilai, moral, dan sikap perilaku siswa.
Sementara itu menurut Winataputra \& Budimansyah [1], Pendidikan Kewarganegaraan (Civic Education) merupakan subjek pembelajaran yang mengemban misi untuk membentuk keperibadian bangsa, yakni sebagai upaya sadar dalam "nation and character building". Dalam konteks ini peran PKn bagi keberlangsungan hidup berbangsa dan bernegara sangat strategis. Suatu negara demokratis pada akhirnya harus bersandar pada pengetahuan, keterampilan dan kebajikan dari warga negaranya dan orang-orang yang mereka pilih untuk menduduki jabatan publik. PKn bertujuan untuk mempersiapkan peserta didik untuk menjadi warga negara yang baik (to be good and smart citizens) yang memiliki komitmen yang kuat dalam mempertahankan kebhinekaan di Indonesia dan mempertahankan integritas nasional.

Konfigurasi atau kerangka sistematik PKn dibangun atas dasar paradigma sebagai berikut: Pertama, PKn secara kurikuler dirancang sebagai subjek pembelajaran yang bertujuan untuk mengembangkan potensi individu agar menjadi warga negara Indonesia yang berakhlak mulia, cerdas, partisipatif, dan bertanggung jawab. Kedua, PKn secara teoretik dirancang sebagai subjek pembelajaran yang memuat dimensidimensi kognitif, afektif, dan psikomotorik yang bersifat konfluen atau saling berpenetrasi dan terintegrasi dalam konteks substansi ide, nilai, konsep, dan moral Pancasila, kewarganegaraan yang demokratis, dan bela negara. Ketiga, PKn secara programatik dirancang sebagai subjek pembelajaran yang menekankan pada isi yang mengusung nilai-nilai (content embedding values) dan pengalaman belajar (learning experience) dalam bentuk berbagai perilaku yang perlu diwujudkan dalam kehidupan sehari-hari dan merupakan tuntutan hidup bagi warga negara dalam kehidupan bermasyarakat, berbangsa, dan bernegara sebagai penjabaran lebih lanjut dari ide, nilai, konsep, dan moral Pancasila, kewarganegaraan yang demokratis, dan bela negara.

Cholisin [5], menyatakan bahwa PKn adalah aspek pendidikan politik yang fokus materinya adalah peranan warga negara dalam kehidupan 
bernegara yang kesemuanya itu diproses dalam rangka untuk membina peranan tersebut sesuai dengan ketentuan Pancasila dan UUD 1945 agar menjadi warga negara yang dapat diandalkan oleh bangsa dan negara.Sementara itu, Numan Soemantri [6] menyatakan bahwa PKn adalah program pendidikan yang berintikan demokrasi politik yang diperluas dengan sumber-sumber pengetahuan lainnya diproses guna melatih siswa untuk berfikir, menganalis, bersikap dan bertindak secara demokratis.

Berkaitan dengan pengertian PKn ini Somantri [6] menjelaskan bahwa PKn merupakan usaha untuk membekali peserta didik dengan pengetahuan dan kemampuan dasar yang berkenaan dengan hubungan antara warga negara dengan negara serta pendidikan pendahuluan bela negara agar menjadi warga negara yang dapat diandalkan oleh bangsa dan negara.Dari beberapa pengertian di atas jelas bahwa PKn merupakan mata pelajaran yang memiliki fokus pada pembinaan karakter warga negara dalam perspektif kenegaraan, dimana diharapkan melalui mata pelajaran ini dapat terbina sosok warga negara yang baik (good citizenship).

Sebagaiman lazimnya suatu bidang studi yang diajarkan di sekolah, materi PKn menurut Branson [7] harus mencakup tiga komponen, yaitu Civic Knowledge (pengetahuan kewarganegaraan), Civic Skills (keterampilan kewarganegaraan), dan Civic Disposition (watak kewarganegaraan). Komponen pertama, civic knowledge berkaitan dengan kandungan atau nilai apa yang seharusnya diketahui oleh warga negara [7]. Aspek ini menyangkut kemampuan akademik keilmuan yang dikembangkan dari berbagai teori atau konsep politik, hukum dan moral. Dengan demikian, mata pelajaran PKn merupakan bidang kajian multidisipliner. Secara lebih terperinci, materi pengetahuan kewarganegaraan meliputi pengetahuan tentang hak dan tanggung jawab warga negara, hak asasi manusia, prinsip-prinsip dan proses demokrasi, lembaga pemerintah dan non-pemerintah, identitas nasional, pemerintahan berdasar hukum (rule of law) dan peradilan yang bebas dan tidak memihak, konstitusi, serta nilainilai dan norma-norma dalam masyarakat.
Kedua, Civic Skills meliputi keterampilan intelektual (intellectual skills) dan keterampilan berpartisipasi (participatory skills) dalam kehidupan berbangsa dan bernegara. Contoh keterampilan intelektual adalah keterampilan dalam merespon berbagi persoalan politik, misalnya merancang dialog dengan DPRD. Contoh keterampilan berpartisipasi adalah keterampilan menggunakan hak dan kewajibannya di bidang hukum, misalnya segera melapor kepada polisi atas terjadinya kejahatan yang diketahui.

Ketiga, Civic Disposition (watak kewarganegaraan), komponen ini sesungguhnya merupakan dimensi yang paling substantif dan esensial dalam mata pelajaran PKn. Dimensi watak kewarganegaraan dapat dipandang sebagai muara dari pengembangan kedua dimensi sebelumnya. Dengan memperhatikan visi, misi, dan tujuan mata pelajaran PKn, karakteristik mata pelajaran ini ditandai dengan penekanan pada dimensi watak, karakter, sikap dan potensi lain yang bersifat afektif.

Dari pemaparan diatas maka kita dapat menyimpulkan bahwa dilahirkannya pendidikan kewarganegaran dimaksudkan sebagai perisai bagi suatu bangsa untuk menjaga hal-hal buruk atau negatif yang bia merusak bangsa itu sendiri. Kemudian bagi bangsa indonesai lahirnya PKn dimaksudkan sebagai wahana untuk membentuk warganegara yang cerdas terampil \& berkarakter yang setia kepada bangsa dan Negara Indonesai dengan merefleksikan dirinya dalam kebiasaan berfikir dan bertindak sesuai amanat Pancasila \& UUD 1945 serta tetap menjaga bangsa ini walaupun terdapat gempuran dari luar tetapi gempuran tersebut tetap ditangkal dengan nilai moral yang ada pada PKn itu sendiri.

\section{b. Wawasan Global}

Jika ditelisik lebih dalam makna dari wawasan adalah suatu pandangan ataupun sikap yang mendalam terhadap suatu hakekat [8]. Sedangkan global dapat diartikan mendunia Jadi wawasan global adalah pandangan atau sikap yang mendunia.

Pendidikan memiliki keterkaitan erat dengan globalisasi. Untuk itu, pendidikan harus dirancang 
sedemikian rupa yang memungkinkan seorang peserta didik mengembangkan suasana potensi yang dimiliki secara alami dan kreatif dalam penuh kebebasan, kebersamaan dan tanggung jawab. Disamping itu, pendidikan harus menghasilkan lulusan yang dapat memahami masyarakatnya dengan faktor yang dapat mendukung mencapai sukses ataupun penghalang yang menyebabkan kegagalan dalam kehidupan bermasyarakat. Salah satu altematif yang dapat dilakukan adalah mengembangkan pendidikan yang berwawasan global.

Premis untuk memulai pendidikan berwawasan gobal adalah mengetahui bagian dunia yang lain yang harus mengembangkan kesadaran kita bahwa kita akan dapat memahami lebih baik keadaan diri kita sendiri apabila kita memahami hubun gan dengan masyarakat lain dan isu-isu global sebagaimana dikemukakan oleh Psikolog Csikszentmihalyi [9] menyatakan bahwa perkembangan pribadi yang seimbang dan sehat memerlukan "anunderstanding di the complexities dian increasingly complex and interdependent world".

Pendidikan berwawasan global dapat dikaji berdasarkan dua perspektif: Kurikuler dan perspektif Reformasi. Berdasarkan perspektif kurikuler, pendidikan berwawasan global merupakan suatu proses pendidikan yang bertujuan untuk mempersiapkan tenaga terdidik kelas menengah dan profesional dengan meningkatkan kemampuan individu dalam memahami masyarakatnya dalam kaitan dengan kehidupan masyarakat dunia.

Oleh karena itu, pendidikan berwawasan global akan menekankan pembahasan materi yang mencakup: 1) adanya saling ketergantungan diantara masyarakat dunia, b) adanya perubahan yang akan terus berlangsung dari waktu ke waktu, c) adanya perbedaan kultur diantara masyarakat atau kelompok-kelompok dalam masyarakat oleh karena itu perlu adanya upaya untuk saling memahami budaya yang lain, d) adanya kenyataan bahwa kehidupan dunia ini memiliki berbagai keterbatasan antara lain dalam ujud ketersediaan barang-barang kebutuhan yangjarang, dan, and) untuk dapat memenuhi kebutuhan yang jarang tersebut tidak mustahil menimbulkan konflik konflik. Berdasarkan perspektif kurikuler ini, pengembangan pendidikan berwawasan global memiliki implikasi ke arah perombakan kurikulum pendidikan.

Berdasarkan perspektif reformasi, pendidikan berwawasan global merupakan suatu proses pendidikan yang dirancang untuk mempersiapkan peserta didik dengan kemampuan dasar intelektual dan tanggung jawab guna memasuki kehidupan yang bersifat sangat kompetitifdan dengan derajat saling ketergantungan antar bangsa yang amat tinggi. Pendidikan harus mengkaitkan proses pendidikan yang berlangsung disekolah dengan nilai-nilai yang selalu berubah dimasyarakat global.

Implikasi dari pendidikan berwawasan global menurut perspektif reformasi tidak hanya bersifat perombakan kurikulum, melainkan juga merombak sistem, struktur dan proses pendidikan. Pendidikan dengan kebijakan dasar sebagai kebijakan sosial tidak lagi cocok bagi pendidikan berwawasan global. Pendidikan berwawasan global harus merupakan kombinasi antara kebijakan sosial disatu sisi dan disisi lain sebagai kebijakan yang mendasarkan pada mekanisme pasar. Oleh karena itu, sistem dan struktur pendidikan harus bersifat terbuka, sebagaimana layaknya kegiatan yang memiliki fungsi ekonomis, antara lain: 1) fleksibel-Adaptif, berarti pendidikan lebih ditekankan sebagai suatu proses learning dari pada teaching. Pada pendidikan ini Abdul Muis Mappalotteng, Paradigma Pendidikan Berwawasan Global dan Tantangannya karakteristik individu mendapat tempat yang layak; 2) kreatif-demokratis, berarti pendidikan senantiasa menekankan pada suatu sikap mental untuk senantiasa menghadirkan sesuatu yang baru dan orisinil. Secara paedogogis, kreativitas dan demokrasi merupakan dua mata dari sisi uang. Tanpa demokrasi tidak akan ada proses kreatif, sebaliknya tanpa proses kreatif demokrasi tidak akan memiliki makna.

Dari perspektif kurikuler pendidikan berwawasan global berarti menyajikan kurikulum yang bersifat interdisipliner, multidisipliner dan transdisipliner. Berdasarkan perspektif reformasi, 
pendidikan berwawasan global menuntut kebijakan pendidikan tidak semata sebagai kebijakan sosial, melainkan suatu kebijakan yang berada diantara kebijakan sosial dan kebijakan yang mendasarkan mekanisme pasar. Oleh karena itu, pendidikan harus memiliki kebebasan dan bersifat demokratis, fleksibel dan adaptif.

\section{c. Nasionalisme.}

Sebagaimana telah kita lihat, di Indonesia sendiri nasionalisme bukan merupakan sesuatu yang sudah sejak dulu ada. Ia baru lahir dan mulai tumbuh pada awal abad ke-20, seiring dengan lahir dan tumbuhnya berbagai bentuk organisasi pergerakan nasional yang menuntut kemerdekaan dan sistem pemerintahan negara bangsa yang demokratis. Tampak pula bahwa nasionalisme di Indonesia merupakan sesuatu yang hidup, yang bergerak terus secara dinamis seiring dengan perkembangan masyarakat, bahkan sampai sekarang. Makna nasionalisme sendiri tidak statis, tetapi dinamis mengikuti bergulirnya masyarakat dalam waktu.

Nation berasal dari bahasa Latin natio, yang dikembangkan dari kata nascor (saya dilahirkan), maka pada awalnya nation (bangsa) dimaknai sebagai "sekelompok orang yang dilahirkan di suatu daerah yang sama" (group of people born ini the same place) [10]. Kata 'nasionalisme' menurut Abbe Barruel untuk pertama kali dipakai di Jerman pada abad ke-15, yang diperuntukan bagi para mahasiswa yang datang dari daerah yang sama atau berbahasa sama, sehingga mereka itu (di kampus yang baru dan daerah baru) tetap menunjukkan cinta mereka terhadap bangsa/suku asal mereka [10]. Nasionalisme pada mulanya terkait dengan rasa cinta sekelompok orang pada bangsa, bahasa dan daerah asal usul semula. Rasa cinta seperti itu dewasa ini disebut semangat patriotisme. Jadi pada mulanya nasionalisme dan patriotisme itu sama maknanya.

Namun sejak revolusi Perancis meletus 1789, pengertian nasionalisme mengalami berbagai pengertian, sebab kondisi yang melatarbelakanginya amat beragam. Antara bangsa yang satu dengan bangsa yang lain. Nasionalisme bukan lagi produk pencerahan Eropa tetapi menjadi label perjuangan dinegara-negara Asia-Afrika yang dijajah bangsa Barat. Keragaman makna itu dapat dilihat dari sejumlah pendapat berikut. Smith [11] memaknai nasionalisme sebagai gerakan ideologis untuk meraih dan memelihara otonomi, kohesi dan individualitas bagi satu kelompok sosial tertentu yang diakui oleh beberapa anggotanya untuk membentuk atau menentukan satu bangsa yang sesungguhnya atau yang berupa potensi saja. Snyder [12] sementara itu memaknai nasionalisme sebagai satu emosi yang kuat yang telah mendominasi pikiran dan tindakan politik kebanyakan rakyat sejak revolusi Perancis. Ia tidak bersifat alamiah, melainkan merupakan satu gejala sejarah, yang timbul sebagai tanggapan terhadap kondisi politik, ekonomi dan sosial tertentu. Sementara itu Carlton Hayes, seperti dikutip Snyder [12] membedakan empat arti nasionalisme: Sebagai proses sejarah aktual, yaitu proses sejarah pembentukan nasionalitas sebagai unit-unit politik, pembentukan suku dan imperium kelembagaan negara nasional modern. (2) Sebagai suatu teori, prinsip atau implikasi ideal dalam proses sejarah aktual. (3) Nasionalisme menaruh kepedulian terhadap kegiatan-kegitan politik, seperti kegiatan partai politik tertentu, penggabungan proses historis dan satu teori politik. (4) Sebagai satu sentimen, yaitu menunjukkan keadaan pikiran di antara satu nasionalitas.

Sementara itu Benedict Anderson [13] mendefinisikan nation (bangsa) sebagai "suatu komunitas politis yang dibayangkan dan dibayangkan sekaligus sebagai sesuatu yang secara inheren terbatas dan berdaulat" (an imagined political community and imagined as both inherently limited and sovereign"). Istilah dibayangkan (imagined) ini penting, menurut Anderson, mengingat bahwa anggota-anggota dari nasion itu kebanyakan belum pernah bertemu satu sama lain, tetapi pada saat yang sama di benak mereka hidup suatu bayanganbahwa mereka berada dalam suatu kesatuan komuniter tertentu. Karena terutama hidup dalam bayangan (dalam arti positif) manusia yang juga hidup dan berdinamika, nasionalisme disini dimengerti 
sebagai sesuatu yang hidup, yang terus secara dinamis mengalami proses pasang surut, naik turun. Pandangan yang demikian ini mengandaikan bahwa nasionalisme merupakan sesuatu yang hidup, yang secara dinamis berkembang serta mencari bentuk-bentuk baru sesuai dengan perkembangan dan tuntutan jaman.

Boyd Shafer [14] mengatakan bahwa nasionalisme itu multi makna, hal tersebut tergantung pada kondisi objektif dan subjektif darisetiap bangsa. Oleh sebab itu nasionalisme dapat bermakna sebagai berikut: (1) Nasionalisme adalah rasa cinta pada tanah air, ras, bahasa atau budaya yang sama, maka dalam hal ini nasionalisme sama dengan patriotisme. (2) Nasionalisme adalah suatu keinginan akan kemerdekaan politik, keselamatan dan prestise bangsa. (3) Nasionalisme adalah suatu kebaktian mistis terhadap organisme sosial yang kabur, kadang-kadang bahkan adikodrati yang disebut sebagai bangsa atau Volk yang kesatuannya lebih unggul daripada bagian-bagiannya.

Nasionalisme adalah dogma yang mengajarkan bahwa individu hanya hidup untuk bangsa dan bangsa demi bangsa itu sendiri. (5) Nasionalisme adalah doktrin yang menyatakan bahwa bangsanya sendiri harus dominan atau tertinggi di antara bangsa-bangsa lain dan harus bertindak agresif. Kendati ada beragam definisi tentang nasionalisme, Hans Kohn [15] menggarisbawahi bahwa esensi nasionalisme adalah sama, yaitu " $a$ state of mind, in which the supreme loyality of the individual is felt to be due the nation state" (sikap mental, di mana kesetiaan tertinggi dirasakan sudah selayaknya diserahkan kepada negara bangsa).

Dari urain di atas kita dapat menarik suatu kesimpulan bahwa nasionalisme merupakan suatu bentuk rasa kebersamaan serta ikatan pesaudaraan dari sekelompok orang yang mendiami suatu wilayah tertentu. Ikatan rasa persaudaraan ini muncul bukan dikarenakan ikatan darah tetapi dikaranekan adanya persaan senasip sepenanggungan karena merasakan atau mengalami hal-hal tertentu yang hamper mirip atau sama.
Setelah mengkaji hal-hal pokok diatas maka yang perlu kita perhatikan adalah apa saja nilai yang sangat medasar yang harus dijalankan supaya nilai-nilai yang ada dalam pembelajaran PKn dapat muncul secara maksimal dan berguna bagi masyakat. Dengan memunculkan kembali nilainilai yang kurang diperhatikan dalam PKn diharapkan muncul wawasan-wawasan yang mengglobal dari setiap warga Negara tetapi tetap dijiwai oleh rasa nasionalisme yang tinggi. Dengan adanya nasionalisme maka seorang warga Negara yang memilki wawasan keilmuan yang mempuni akan menggunakan semua kemampuannnya secara maksimal demi kebaikan bangsa Indonesia. Hal-hal dasar tersebut yang harus dimiliki oleh setiap warga Negara supaya dapat memunculkan kembali nilai-nilai dasar yang terkandung dalam PKn yang akan bermafaat bagi orang banyak. Nilai-nilai dalam pembelajaran PKnharus dimunculkan serta dimaksimalkanantara lain:

Pertama, pada nilai ketuhanan, manusia Indonesia selain mencintai Tuhan, juga sanggup mencintai sesama tanpa memandang suku, agama, ras, dan golongan. Butir sila Ketuhahan Yang Maha Esa. Hormat dan menghormati serta bekerjasama antara pemeluk agama dan penganutpenganut kepercayaan yang berbeda-beda sehingga terbina kerukunan hidup. Saling menghormati kebebasan menjalankan ibadah sesuai dengan agama dan kepercayaan masingmasing, serta tidak memaksakan suatu agama atau kepercayaannya kepada orang lain. Oleh karena itu kita sebagai warga Negara yang sudah engenyam pendidikan dan memiliki wawasan lebih di dalam masyarakat bisa memberikan wawasan kepada masyarakat untuk menekankan toleransi antarumat beragama, toleransi sebagai bangsa yang berbhineka, dan merlarang berbagai bentuk kekerasan, dan menekankan adanya pluralitas dan multikulturalisme. Walaupun negara kita dikenal dunia sebagai negara berpenduduk muslim terbesar di dunia, namun rakyat Indonesia tidak pernah merasa menjadi negara muslim, tetapi tetap menjunjung tinggi negara Pancasila. Setiap warga negara harus berlomba-lomba memberi contoh baik dalam kegiatan berbangsa dan 
bernegara. Menghormati antarpemeluk agama, menghormati perbedaan sebagai suku bangsa, menghormati perbedaan ras, dan golongan. Berlomba-lomba untuk mengasihi sesama umat manusia, sesama bangsa Indonesia, khususnya mereka yang miskin dan papa. Jangan hanya merasa kasihan dengan mereka yang miskin, tetapi dapat berbuat untuk menolong. Menghormati serta bekerjasama antara pemeluk agama dan penganutpenganut kepercayaan yang berbeda-beda sehingga terbina kerukunan hidup serta masyarakat yang berwawasan global akan muncul yang didasari oleh nasionalisme. Simpul-simpul keagaamaan yang diyakini setiap warganegara makin memperkuat persaudaraan atau nasionalime.

Kedua, pada nilai kemanusiaan, nilai-nilai kemanusiaan seperti saling mencintai sesama manusia, mengembangkan sikap tenggang rasa, tidak semena-mena terhadap orang lain, menjunjung tinggi nilai kemanusiaan, gemar melakukan kegiatan kemanusiaan, dan berani membela kebenaran dan keadilan tidak hanya dipahami tetapi diaplikasikan dalam kehidupan. Nilai-nilai tersebut sangat subur dalam kultur masyarakat Indonesia. Setiap terjadi bencana nasional seperti gempa bumi, erupsi gunung berapi, banjir, tanah longsor, rakyat sigap mengekspresikan nilai Pancasila tersebut secara nyata. Masyarakat membuat dapur umum, membungkusi nasi, mendistribusikan kepada korban tanpa dikomando. Para dokter baik secara perorangan maupun lembaga, bersatu padu menolong mereka yang sakit dan terluka. Lembaga masyarakat nonpemerintah membangun barak, bahkan memulihkan trauma pasca benacana. Semua yang dilakukan itu adalah gaya khas bangsa Indonesia, ketika melihat penderitaan bersama. Ini juga merupkan hal yang akan mempererat rasa persadaraan atau bisa memunculkan rasa nasionalisme yang tinggi sesame warga bangsa.

Ketiga, pada nilai persatuan, persatuan disini dimaksudkan bahwa walalupun warga Negara kita bersal dari kalangan yang sangat beraneka ragam. Nilai Persatuan Indonesia mengandung arti ke arah bersatu dalam kebulatan rakyat untuk membina Nasionalisme dalam negara. Nilai Persatuan Indonesia yang demikian ini merupakan suatu proses untuk menuju terwujudnya Nasionalisme. Dengan modal dasar nilai persatuan, semua warga Indonesia baik yang asli maupun keturunan asing dan dari macam-macam suku bangsa dapat menjalin kerjasama yang erat dalam wujud gotongroyong, kebersamaan.

Dalam nilai persatuan terkandung adanya perbedaan-perbedaan yang biasa terjadi didalam kehidupan masyarakat dan bangsa , baik itu perbedaan bahasa, kebudayaan, adat-istiadat, agama, maupun suku. Perbedaan-perbedaan itu jangan dijadikan alasan untuk berselisih, tetapi justru menjadi daya tarik ke arah kerjasama, ke arah resultante/sintesa yang lebih harmonis. Hal ini sesuai dengan semboyan "Bhinneka Tunggal Ika”. Dalam membangun kebersamaan sebagai wujud nilai Persatuan itu antar elemen yang terlibat didalamnya, satu sama lain saling membutuhkan, saling ketergantungan, saling memberi yang pada gilirannya dapat menciptakan kehidupan selaras,serasi dan seimbang. Kehidupan demikian ini sebagai dambaan bangsa Indonesia

Keempat, Nilai kompetisi, kompetisi disini dimaksudkan guna pengembangan berbagai macam kemampuan yang dimiliki manusia, bukan malah menjadi ajang perdebatan. Semua orang dengan potensi dan kadar kemampuan masingmasing, harus berkompetisi dan berlomba-lomba dalam melaksanakan kebaikan. Kompetisi penting dijalankan karena melakukan kebaikan tidak seharusnya ditunda-tunda, melainkan harus segera dikerjakan. Sebab kesempatan hidup sangat terbatas, begitu juga kesempatan berbuat baik belum tentu setiap saat kita dapatkan. Kematian bisa datang secara tiba-tiba tanpa diketahui sebabnya. Oleh karena itu, begitu ada kesempatan untuk berbuat baik, janganlah kita tunda-tunda lagi, tetapi harus segera kita kerjakan.

Bahwa hendaknya saling memotivasi dan saling tolong-menolang untuk berbuat baik, di sinilah perlunya kolaborasi atau kerja sama. Tanda-tanda lingkungan yang baik adalah lingkungan yang membuat kita terdorong untuk berbuat baik. Tidak sedikit seorang yang tadinya baik menjadi rusak karena lingkungan. 
Lingkungan yang saling mendukung kebaikan akan tercipta kebiasaan berbuat baik secara konsisten. Kesigapan melakukan kebaikan haruslah didukung dengan kesungguhan. Langkah awal untuk menciptakan suatu lingkungan yang baik adalah dengan memulai dari diri sendiri, dari yang terkecil, dan dari sekarang. Sebab inilah jalan terbaik dan praktis untuk memperbaiki sebuah bangsa. Kita harus segera memulai dari diri sendiri dan keluarga. Sebuah bangsa, apa pun hebatnya secara teknologi, tidak akan bisa pernah tegak dengan kokoh jika pribadi dan keluarga yang ada di dalamnya sangat rapuh.

Contoh paling sederhana mengenai kompetisi sehat adalah bagaimana rasa leganya seseorang ketika dia memenangi sebuah laga dengan modal kemampuan yang dimilikinya tanpa ada trik-trik licik, tentu sangat bahagia. Bandingkan dengan orang yang menang dengan cara curang, secara batin dia tidak akan pernah puas dangan cara yang ditempuhnya. Surga dunia adalah ketika secara batin orang tidak terjajah dengan kegelisahan, ketakutan dan rasa was-was. Sebaliknya, neraka dunia adalah kondisi batin yang dikekang oleh rasa tidak nyaman seseorang karena banyak melakukan penyimpangan.

Dari uraian di atas diharapkan akan memunculkan kesadaran yang tinggi serta wawasan yang luas di dalam diri. Dengan kesadaran bahwa kita merasakan adanya kebutuhan memahami masalah global, serta dengan wawasan yang luas kita dapat memilih dan memilah informasi atau nilai mana yang diperlukan dan mana yang tidak, mana yang sesuai dengan nilai budaya kita dan mana yang tidak. Wawasan menggelobal yang dimiliki oleh warga bangsa juga tidak akan mengikis rasa nasionalisme yang mana hal ini bisa pergunakan untuk menyatukan beberapa perbedaan, karena nasionalisme lebih mengutamakan kepentingan umum dari pada kepentingan individu. Jika nasionalisme dapat tertanam pada setiap individu warga Indonesia, maka negara yang bersifat pluralistis ini, artinya negara yang didalamnya terdapat banyak keragaman dan perbedaan, akan menjadi negara yang damai tanpa ada konflik etnik dan konflik kefanatikan terhadap daerahnya
masing-masing.Nasionalisme ini akanmampu menangkal perbedaan suku, adat-istiadat, ras dan agama.Yang baik harus kita ambil dan yang buruk kita tinggalkan.

\section{KESIMPULAN}

Dari kajian yang telah dilakukan dapat disimpulkan bahwa ada nilai-nilai dasar utama yang perlu dikembangkan dalam pendidikan kewarganegaraan untuk membangun wawasan global warga Negara yang dijiwai rasa nasionalisme. Nilai-nilai dasar yang perlu dikembangkan dalam membangun wawasan global dalam konteks Indonesia antara lain ketuhanan, kemanusiaan, persatuan, kerakyatan, keadilan sosial, kompetisi, menghormati orang lain, kemerdekaan dan perdamaian. Nilai-nilai dasar ini penting untuk dikembangkan dalam rangka mengembangkan wawasan global warga Negara yang semnagat didalamnya tetapdijiwai oleh rasa nasionalime agar dapat berperan secara efektif dalam kancah global tanpa meninggalkan jati diri sebagai bangsa Indonesia yang memiliki Pancasila sebagai falsafah dalam kehidupan berbangsa dan bernegara.

\section{DAFTAR PUSTAKA}

[1] Winataputra \&Budimansyah. PKn dalam Perspektif Internasional (Konteks, Teori, dan Profil Pembelajaran).Bandung: Widya Aksara Pers. 2012

[2] Cogan,J. J. Developing the civic society: the role of civic education. Bandung. CICED. 1999

[3] Djahiri, K. Pendidikan nilai moral dalam dimensi pendidikan kewarganegaraan. Bandung: Laboratorium PKn FPIPS UPI. 2006

[4] Komalasari, K \& syaifullah. Kewarganegaraan Indonesia konsep perkembangan dan masalah kontemporer. Bandung: Lab PKn UPI. 2009

[5] Cholisin. Materi pokok ilmu kewarganegaraan-pendidikan kewarganegaraan. Yogyakarta: UNY Press. 2007

[6] Somantri, N. Menggagas pembaharuan pendidikan IPS. Bandung: PT Remaja Rosdakarya. 2001

[7] Branson.. Belajar "Civic Education" dari Amerika (Terjemahan Syaripudin, dkk). Yogyakarta: Lembaga Kajian Islam dan Sosial (LKIS). 1999

[8] Depdikbud. Buku II Keterampilan Berbicara dan Pengajaranya. Jakarta. 1985

[9] Csikszentmihalyi, M. The Evolving Self: A Psychology for the Third Millennium. New York: HarperCollins. 1993.

[10] Ritter, Herry. Dictionary of Concepts in History. New York: Greenwood Press. 1986

[11] Smith, A. D. Nationalist Movement. London: The Macmillan Press. 1979. 


\section{J U R N A L Jurnal PIPSI: Jurnal Pendidikan Ilmu Pengetahuan Sosial Indonesia}

\section{Volume 1 Nomor 1 Bulan Maret, 2016 Halaman 14-23}

p.ISSN: 2477-6254 e-ISSN: 2477-8427

[12] Snyder, L. L. The Dynamic of Nationalism. Princeton: D. Van Nostrand Co. Inc. Shafer, Boyd C. 1955. Nationalism Myth and Reality. New York: A Harvest. 1964.

[13] Anderson, Benedict. Imagined Communities. London and New York. 1996

[14] Shafer, Boyd. Nationalism:myth and reality. Mishawaka: Harcourt, Brace. 1955
[15] Book Harcourt Kohn, H..The Idea of Nationalism. Toronto: Cillier Books. 1969. 